\title{
Hyperhaemolytic Syndrome in Sickle Cell Disease: Clearing the Cobwebs
}

\author{
Anazoeze Jude Madu ${ }^{a}$ Angela Ogechukwu Ugwu ${ }^{\mathrm{a}}$ Chilota Efobi ${ }^{\mathrm{b}}$ \\ ${ }^{a}$ Department of Haematology and Immunology, University of Nigeria Ituku-Ozalla Campus, Ituku-Ozalla, Nigeria; \\ ${ }^{b}$ Department of Haematology, Nnamdi Azikiwe University, Nnewi, Nigeria
}

\section{Significance of the Study}

- Hyperhaemolysis, uncommon syndrome in some sickle cell disease patients, reoccurs suggesting an immunological and/or genetic predisposition.

- Variations in MBL2 and KLCR3 are responsible for synthesis of key complement pathway proteins.

- $\mathrm{HbA} / \mathrm{HbS}$ ratio is unchanged in hyperhaemolytic syndrome compared to delayed-type hypersensitivity reaction (DTHR), where HbA drops disproportionately.

- HbA appears in urine with worsening anaemia and reticulocytopenia.

- Treatment with rituximab or tocilizumab/erythropoietin is better than steroids alone.

\section{Keywords}

Hyperhaemolysis · Sickle cell · Severe anaemia .

Reticulocytopaenia

\begin{abstract}
Sickle cell disease (SCD) presents with a dynamic background of haemolysis and deepening anaemia. This increases the demand for transfusion if any additional strain on haemopoiesis is encountered due to any other physiological or pathological causes. Patients with cerebrovascular accidents are placed on chronic blood transfusion; those with acute sequestration and acute chest syndrome are likewise managed with blood transfusion. These patients are prone to develop complications of blood transfusion including alloimmunization and hyperhaemolytic syndrome (HHS). This term
\end{abstract}

is used to describe haemolysis of both transfused and "own" red cells occurring during or post-transfusion in sickle cell patients. Hyperhaemolysis results in worsening post-transfusion haemoglobin due attendant haemolysis of both transfused and autologous red cells. The mechanism underlying this rare and usually fatal complication of SCD has been thought to be secondary to changes in the red cell membrane with associated immunological reactions against exposed cell membrane phospholipids. The predisposition to $\mathrm{HHS}$ in sickle cell is also varied and the search for a prediction pattern or value has been evasive. This review discusses the pathogenesis, risk factors and treatment of HHS, elaborating on what is known of this rare condition.

C) 2020 The Author(s)

Published by S. Karger AG, Basel karger@karger.com www.karger.com/mpp

Karger $\stackrel{\text { ' }}{5}$

BOPEN ACCESS
(C) 2020 The Author(s)

Published by S. Karger AG, Basel

This is an Open Access article licensed under the Creative Commons Attribution-NonCommercial-4.0 International License (CC BY-NC) (http://www.karger.com/Services/OpenAccessLicense), applicable to the online version of the article only. Usage and distribution for commercial purposes requires written permission.
Anazoeze Jude Madu

Department of Haematology and Immunology, College of Medicine University of Nigeria, Ituku-Ozalla Campus

UNTH Ituku-Ozalla, 100049, Ituku-Ozalla, Enugu State (Nigeria) anazoeze.madu@unn.edu.ng 


\section{Introduction}

More than 250 million persons worldwide, especially those of African descent, are afflicted with sickle cell disease (SCD). This is a genetic disorder inherited in an autosomal recessive manner; it involves a point mutation in the beta-globin gene where thymine replaces adenine leading to a production of valine in place of glutamic acid which characterizes the abnormal haemoglobin (HBS) formed. This single mutation causes a myriad of clinical syndromes manifesting in every organ/system in the affected individual. Patients with SCD present with vasoocclusive painful crises, splenic/hepatic sequestration, stroke, nephropathy, acute chest syndrome, severe anaemia, and a host of other manifestations. Several of these clinical features require blood transfusion either as topup or exchange blood transfusion. Acute exacerbations often occur and include vaso-occlusive crises, hyperhaemolytic crises, aplastic crises, acute chest syndrome, stroke, and priapism [1]. The treatment for several complications of sickle cell anaemia (SCA) involves blood transfusion be it severe anaemia, stroke, aplastic crisis, or acute chest syndrome $[1,2]$. Thus, many SCA patients receive multiple transfusions in their life time. The dangers associated with multiple transfusions in sickle cell has been described in several studies and primarily highlights alloimmunization which further complicates other important complications include febrile haemolytic blood transfusion reaction, transfusion-related acute lung injury, iron overload, delayed haemolytic transfusion reaction (DHTR), and hyperhaemolysis syndrome (HHS) to mention but a few. Infectious complications of transfusion also include malaria, HIV, hepatitis B and C as well as cytomegalovirus, with variations in geographical prevalence [3].

The haemolytic complication transfusion peculiar to sickle cell patients includes hyperhaemolysis, a rare haemolytic syndrome, usually triggered by transfusion, in which both the donor's and recipient's red cells are destroyed leading to a lower post-transfusion HBS level [4]. In such cases, there is an unexpected drop in the posttransfusion concentration of HBS with attendant loss of both donor and recipient red cells. The severity and rapid deterioration of clinical and laboratory parameters in affected patients make it important for clinicians to entertain a high index of suspicion. The clinical presentation is varied depending on the rapidity of onset and will include jaundice, passage of dark urine, worsening anaemia with other symptoms of severe anaemic syndrome [5]. The mechanism underlying this syndrome is not yet very clear. Some researchers have put forward the theory that hyperactive macrophages engulf the red cells. Other mechanisms include inhibition of erythropoiesis, and presence of antibodies and/or undetectable levels of complement. It is our aim in this review to highlight this complication of multiple transfusions seen in patients with SCA and to emphasize the need for prompt diagnosis and recognition of the symptoms of HHS to avert morbidity and/or mortality.

HHS must be differentiated from a delayed haemolytic transfusion reaction which usually occurs with subsequent (and not a first transfusion) and may occur some days to weeks after transfusion. The diagnosis of delayedtype hypersensitivity reaction (DTHR) can be made using the algorithm for adult SCD patients, can be made when a significant decrease in $\mathrm{HbA}(>50 \%)$, and/or in total $\mathrm{Hb}$ levels $(>30 \%)$ are found in the post-transfusion values compared to that pre-transfusion [6]. This reaction is due to haemolysis caused by antibodies to red cell antigens other than $\mathrm{ABO}$ antigens, which are routinely screened in most donor blood samples. It is rarely fatal and only transfused red cells are haemolyzed, and thus, HBS found in the urine of such patients are mainly $\mathrm{HbA}$ (from donor red cells). Red cell electrophoresis or high-performance liquid chromatography (HPLC) done during haemolysis in HHS can also be used to detect lysis of both autologous and transfused red cells as opposed to lysis of only transfused red cells, especially for intravascular haemolysis. The ratio of $\mathrm{HbA} / \mathrm{HbS}$ in $\mathrm{HHS}$ remains unchanged, while in DHTR this decreases due to preferential lysis of the transfused donor A red cells [7]. The clinical features have an insidious onset and most patients present with a suboptimal post-transfusion HBS concentration.

\section{Methodology}

Materials and relevant literature for this study were obtained using online search engines and websites accessed were PubMed, Web of Science, Hinari, JSTOR, and ARDI. The search was conducted using advanced search for the keywords sickle cell, hyperhaemolysis, transfusion, crisis, and treatment. This was done after each keyword was processed with $\mathrm{MeSH}$ terms on PubMed. This initial search yielded 115 published items which we further checked for relevance and date of publication. Final publications to be used were accessed and saved on Zetero referencing app. These included original research, review articles, and case reports.

\section{Epidemiology}

This syndrome occurs in all age groups affecting adults as well as children with SCA/SCD [8]. The actual incidence of HHS among sickle cell patients is not known, and however, previous small-scale studies seem to show it occurs more in children than 
Fig. 1. Destruction of red cells and reticulocytes by activated macrophages due to exposure of phosphatidylserine. From Win et al. [15].

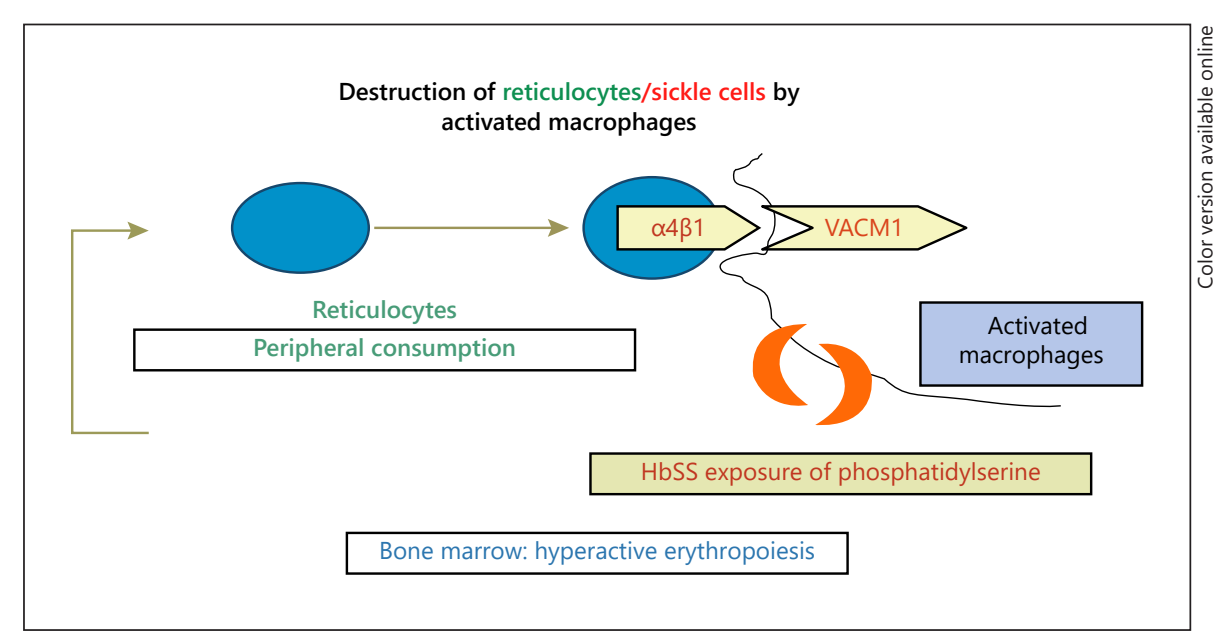

in adults [9]. The reason is because HHS being a rare complication of transfusion in SCD is difficult to diagnose and are often missed due to misdiagnosis or under-reporting. It is usually believed that episodes of HHS may present as painful vaso-occlusive crises seen in SCD patients who have received blood transfusion $[10,11]$. This further makes accurate diagnosis a difficult task. However, an incidence of HHS of 5.1 and $1.6 \%$ was found in paediatric and adult SCD patients, respectively [12]. Mwesigwa et al. [13] also found a prevalence of $3-5 \%$ among their patients. This may be due to early mortality in predisposed paediatric cases leading to a waning prevalence going into adulthood. A prospective study targeted at screening transfused SCD patients in the immediate post-transfusion period is needed to extract the exact prevalence of HHS.

\section{Clinical Features}

Hyperhaemolysis syndrome could be acute or delayed. The acute type usually occurs within 7 days of the patient receiving blood transfusion, and no new antibodies against the transfused RBCs are usually detected; the direct antiglobulin test (DAT) is found to be negative in these patients. Delayed type of HHS is usually seen more than 7-day post-transfusion, and this is accompanied by formation of antibodies and a positive DAT [8]. Very few cases of HHS have been reported to be recurrent. Patients with HS present with back pain, abdominal pain, joint pain, weakness, haemoglobinuria, jaundice [5], and fever [14].

\section{Pathogenesis and Features}

\section{Pathogenesis}

The key features of HHS are the destruction of both autologous and donor red cells; marrow red cells precursors may be destroyed, but this occurs only in a few sickle cell patients. Another key feature is that it tends to reoccur in the same patient following subsequent transfusion [8]. This portends an immunological or genetic predisposition akin to features of a secondary immune response. Several theories have been put forward to ex- plain the mechanism of HHS. Till date, there has been no scientifically proven mechanism to completely describe the findings in HHS $[5,15]$. Sickle cell patients are more at risk of being multiply transfused with consequent development alloantibodies against $\mathrm{RBC}$ antigens in the donor units. The titre of the alloantibodies wanes over time to undetectable levels. With subsequent exposure to the same red cell antigens, there is an anamnestic reaction with haemolysis of both the autologous and donor red cells $[16,17]$. It has been postulated that the red cell destruction is mainly effected by hyperactive macrophages.

Red cells may undergo injury from several factors like osmotic shock, oxidative stress, or depletion of ATP. These lead to the production of prostaglandin E2 via the cyclooxygenase pathway with consequent activation of $\mathrm{Ca}^{2+}$ permeable cation channels with resultant increase in calcium influx and cytoplasmic $\mathrm{Ca}^{2+}$. This also causes the opening of calcium-sensitive potassium channels with loss of intracellular potassium, followed by activation of the enzyme scramblase which is responsible for moving phosphatidylserine (PS) to the outer leaflet of the red cell membrane. This enzyme is primed for this calcium-dependent activation by the effect of ceramide derived from the effect of stressors (like osmotic shock) on sphingomyelinase. Phospholipase A2 secreted by inflammatory cells cause release of platelet-activating factor (PAF) which activates sphingomyelinase [18] Exposure of PS on the red cell surface is a signal for macrophage phagocytosis. Exposure of PS together with eryptosis or red cell shrinking is similar to the features of apoptosis seen in nucleated cells.

Under normal circumstances, phospholipids are asymmetrically distributed across the cell membrane lipid bilayer with PS and phosphatidylethanolamine being 
predominantly found in the inner leaflet, and cholinecontaining phospholipids phosphatidylcholine (PC) and sphingomyelin on the outer leaflet [19]. It is known that in SCA, the lipid bilayer on the red cell membrane undergoes a "flip-flop" distortion with the PS and phosphatidylethanolamine predominating on the outer leaflet of the red cell membrane. This exposure is actually driven by the oxidative nature of the plasma in SCD [20]. PS is a cellular indicator which leads to eryptosis and may cause lysis of both autologous and transfused red cells. The exposure of the amino phospholipids facilitates "attraction" to macrophages which then engulf them. This process is enhanced by an increased number of adhesion molecules on these red cell membranes [8]. Figure 1 shows a pictorial representation of the increased expression of adhesion molecules on reticulocytes with consequent exposure of PS leading to macrophage phagocytosis. This process of phagocytosis of red cells with distorted membrane lipids performed by macrophages mainly in extravascular tissues. However, in HHS, both intravascular and extravascular haemolysis goes on concurrently in affected patients. This should be distinguished from the direct destruction of red cells by lysing antibodies in the intravascular space with consequent haemoglobinuria.

The mechanism underlining HHS which occurs without detectable antibodies is poorly understood and is, therefore, not easily diagnosed or treated as opposed to DHTR. This has been postulated to be due to reactive haemolysis, and possible continuation of haemolysis of autologous RBCs following bone pain crisis [21, 22]. Donor red cells incubated in the pre-transfusion plasma of SCD patients with DTHR caused eryptosis of stored red cells [18]. Eryptosis is the term used to describe antibody-independent red cell death characterized by erythrocyte shrinkage, membrane blebbing, and PS exposure [18]. This phenomenon occurs in both transfused and autologous red cells. Lysis of transfused red cells in SCD plasma has been reported and may be due to the presence of circulating toxic inflammatory factors like Duffy (FY) a binding protein for chemokines. This may be more abundant in transfused than in autologous red cells and has been described in transfusion across races with variations in red cell antigen distribution.

Another mechanism which was postulated was that of a bystander complement activation on the surfaces of autologous red cells which then leads to haemolysis of these cells. This process is believed to be activated by antibodies against donor antigens present in the patient's serum [23]. The red cell destruction, in this case is, therefore, believed to be an "immunological accident" which not

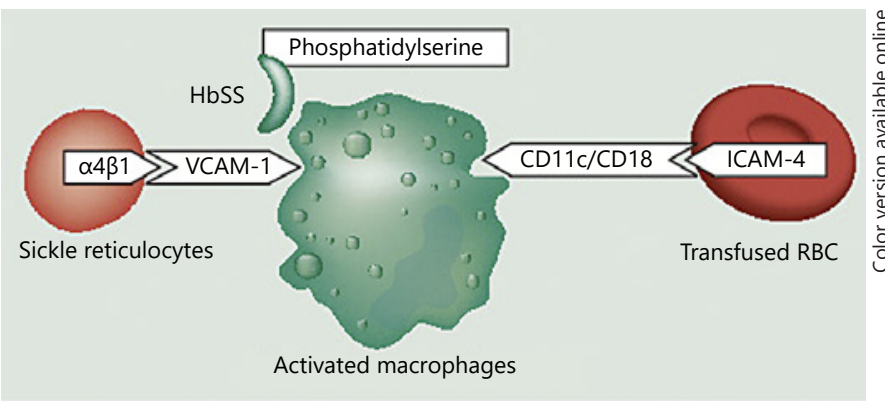

Fig. 2. Interaction and destruction of the patient's own cells (HbSS/ reticulocytes) and transfused cells by activated macrophages.

only affects mature red cells but also the marrow erythroid precursors leading to the reticulocytopenia observed in some cases. Researchers have also shown that there is a defective regulation of the membrane attack complex (MAC) on the RBCs of patients with SCA. The defective regulation of MAC may explain destruction of transfused as well as autologous RBC by complement. This would affect all red cell precursors which express the target antigens VCAM- 1 and $\alpha 4 \beta 1$, hence, the reticulocytopenia and paucity of red cell precursors seen in some [24]. Figure 2 shows the ligands $\alpha 4 \beta 1$ and ICAM- 4 on transfused red cells and reticulocytes and their receptors VCAM-1 and CD11c/CD18 on macrophages.

\section{Predisposing Factors}

Certain factors have been found to predispose patients to HHS. These factors include recurrent blood transfusion leading to alloimmunization, patient's blood group, and history of infection [25]. Bystander complement activation is considered as one of the mechanisms that drive HHS. These factors may help physicians refine risk-benefit assessments for transfusion and guide further therapeutic development.

\section{Genetic Considerations}

About 5\% of SCD patients who receive recurrent transfusions go on to develop HHS whereas the rest do not [13]. With recurrent transfusion, a higher prevalence of alloantibodies with subsequent immediate or delayed post-transfusion haemolysis would be expected in any other cohort. This observation has given rise to a hypothesis that there are possible genetic factors responsible for increased susceptibility to HHS by the SCD patients [13]. Though genetic factors are being studied has been ob- 
served that individuals with non-B blood type are 9.8 times more likely to develop HHS [25]. Genome-wide association studies in sickle cell patients with hyperhaemolysis had indicated that a set of genes may predispose to this complication. The fact that only a small group of patients seem to be predisposed to HHS also supports the likelihood of genetic predisposition. Mwesigwa et al. [26] found that MBL2 (mannose-binding lectin 2) was significantly enriched in HHS cases and that the final exon of KLCR3 (killer cell lectin-like receptor subfamily C, member 3) had an insertion-deletion variant in a majority of the paediatric HHS cases. Interestingly, both genes are involved in the production of proteins and ligands needed in the complement pathway which helps to sharpen immune response. The unchecked production of these 2 protein ligands involved in the complement pathways leading up to the exaggerated production of the MAC will portend increased destruction of most non-nucleated cells, red cell inclusive. This may indeed support the previous observations that HHS is both a genetic and immunological disposition found in a few patients.

\section{Previous Transfusion}

A direct relationship exists between the number of blood units transfused and the development of alloantibodies. Patients who have received 10 or more units of red-cell transfusion were found to have a 10 -fold risk of being alloimmunized $[27,28]$. This leads to the patient developing alloantibodies to target red cell antigens. Anti-Kidd antibodies are common causes of DHTRs as well as HHS. However, alloantibodies have not been detected in HHS, and this has further made it difficult to classify this syndrome as a purely immunological process. These antibodies are difficult to detect during routine antibody screening $[29,30]$. It is known that the presence of these alloantibodies or autoantibodies makes future transfusions unsafe due to higher risks of haemolytic transfusion reactions [31].

\section{Infections}

Aloni et al. [32] found that about $80 \%$ of SCD children with malaria had hyperhaemolysis necessitating hospital admission and treatment. This demonstrates the possible role of infection in hyperhaemolysis [33]. Acute chest syndrome has also been reported as a possible trigger of HHS in children where the pneumonic process is usually bacterial and due to streptococcal infections [34]. These may likely be linked to heightened haemolysis which occurs during parasitaemias and sepsis leading to nitric oxide depletion and consequent immunological (macro- phage) activation. This may further predispose SCA patients to HHS via distortion of the cell membrane phospholipids causing premature autolysis secondary to altered red cell signalling.

\section{Hyperhaemolysis Syndrome in Nonsickle Cell Anaemia}

A greater proportion of HHS occurs in individuals with SCD, and however, it is reported that HHS could also occur rarely in other clinical conditions such as anaemia of chronic disease, chronic lymphocytic anaemia, myelodysplastic syndrome, and lymphomas such as mantle cell lymphoma to mention but a few [35-39]. The mechanism of breakdown of red cells is complex and is yet to be elucidated, but most cases seem to be accompanied by transfusion of the patient with several units of blood over a short period. In some cases, delayed haemolysis is accompanied by the presence of antibodies to other red cell antigens such as $\mathrm{Jk}_{\mathrm{a}}$ [40]. This suggests that in this group of patients, it is more likely caused by alloantibodies to the red cell antigens not routinely screened in blood bank practice.

\section{Laboratory Findings}

\section{Evidence of Exaggerated Destruction of RBC}

Hyperhaemolysis syndrome presents with worsening anaemia and HBS levels lower than the pre-transfusion values. This provides some evidence that the patient's red cells as well as transfused red cells are been haemolyzed as opposed to the haemolysis seen in DHTR that involves mainly the transfused red cells, and the post-transfusion levels would not be expected to be lower than the pretransfusion $\mathrm{Hb}$. There is an unexpected reticulocytopenia [41], raised levels of lactate dehydrogenase, hyperbilirubinaemia, and raised C-reactive protein. Reticulocytopenia does not occur in all cases of HHS and may indicate underlining bone marrow necrosis or infection with Parvovirus B19.

\section{Reticulocytopenia}

It is noteworthy that opinions on reticulocyte counts during hyperhaemolytic crisis are divided. While some researchers noted reticulocytosis [5], other researchers recorded reticulocytopenia. The reticulocytopenia was explained by the hyperactivity of macrophages which engulf the erythroid precursors [15]. Severe anaemia in 
HHS is due to marked reticulocytopenia and peripheral destruction of both the transfused and recipient red cells [42]. One would have expected to see a reticulocytosis response in haemolytic conditions since the bone marrow response would be to increase the red-cell production due to anaemia. Bone marrow necrosis has also been reported in the previous studies of findings in several sickle cell patients and may contribute in part to the reticulocytopenia observed in some HHS patients [43, 44].

\section{Evidence of Autologous Red Cell Destruction}

Both transfused and recipient red cells are destroyed in HHS, and hence, the worsened state of anaemia observed post-transfusion. This can be detected by HBS electrophoresis or HPLC done with urine from patients in the acute phase. This will reveal both $\mathrm{HbA}$ (from the transfused red cells) and HbS (from the recipient's red cells). Delayed haemolytic transfusion reaction and hyperhaemolytic syndrome can both occur simultaneously in SCA. Also in HHS Hb electrophoresis or HPLC of patient red cells shows marked reduction of both $\mathrm{HbA} \%$ and $\mathrm{HbS} \%$ with no change in $\mathrm{HbA} / \mathrm{HbS}$ ratio, while in DTHR this ratio decreases due to preferential lysis of transfused A cells. In DHTR, there are antibodies formed by the recipients which lead to destruction of transfused red cells only. This can be reduced by transfusing extended red cells in combination with Rituximab. However, DHTR may lead to hyperhaemolysis as has been reported in some cases [7]. Compared to HHS in which both autologous and donor red cells are destroyed by largely unknown mechanisms leading to haemoglobin levels lower than the pre-transfusion haemoglobin levels [42]. There is often a negative direct antiglobulin test (DAT) and absence of red cell alloantibodies [16]. In some cases, HS may occur in a background of haemolysis post-transfusion, and in this case, a positive DAT still does not exclude a diagnosis of HS. Urine protein electrophoresis would be helpful in differentiating the two. The haemoglobin electrophoresis using patient's urine would show both "host" haemoglobin (HbS) as well as transfused haemoglobin (HbA).

\section{Treatment}

\section{Red Cell Transfusion}

The management of HHS is mainly supportive. Transfusion of red cell products is not advisable as it exacerbates the haemolysis leading to worsening anaemia. However, if there is vital need for red cell transfusion, one should not hesitate to transfuse antigenically matched red cells. The guideline for management of HS stipulates an extended antigen typing including the $\mathrm{C} / \mathrm{c}, \mathrm{E} / \mathrm{e}, \mathrm{K}, \mathrm{Jka} /$ $\mathrm{Jkb}, \mathrm{Fya} / \mathrm{Fyb}, \mathrm{M} / \mathrm{N}$, and $\mathrm{S} / \mathrm{s}$ at a minimum $[28,45]$. It is important to note that the best form of treatment is prevention of alloimmunization. Patients with SCD should be transfused with antigen-compatible and cross-matched donor red cells each time they require blood transfusion. Therapeutic plasma exchange may also be useful in management of HS as it has been shown to be effective in severe haemolysis [46, 47].

\section{Immunosupression/Steroids}

Some researchers have noted the positive effect of intravenous immunoglobulin and high-dose steroids in management of mild cases of HHS [45]. The use of intravenous immunoglobulin and steroid is believed to suppress the activation of macrophages which also helps in shortening the duration of haemolysis of both the transfused and patient's own red cells [48]. Intravenous steroids have been associated with nephropathy and thrombosis, and oral prednisolone may be considered $[8,48]$. Rituximab has also been used in some cases of HHS in sickle cell which has improved the reticuocyte count [49, 50]. Another drug used in the treatment of HHS is eculizumab which is a C5 convertase inhibitor. This relies on one of the postulated pathogenesis of HHS involving complement activation leading to red cell destruction. Eculizumab helps in stabilizing the red cell membrane and thus limiting haemolysis [51]. Levels of HBS will begin to increase once the haemolysis abates. A few cases of recurrent HHS have been reported, but these are indeed very rare.

\section{Erythropoiesis-Stimulating Agents}

Erythropoietin has also been tried in the management of HHS [50]. Erythropoietin levels has been shown to be low in SCD, it is thought to act by inhibiting the lysis of erythroid precursors either by stimulating erythropoiesis or by preventing neocytolysis $[52,53]$ although this is yet to be validated. Another study suggested optimising erythropoiesis using erythropoietin-stimulating agents and intravenous iron due to the inappropriately low endogenous erythropoietin for the degree of anaemia. They suggested the use of $250-800 \mathrm{u} / \mathrm{kg} /$ dose given 3 times weekly while monitoring closely for hypertension, thrombosis, and bone pain [54].

More recent studies have suggested the use of tocilizumab, an interleukin-6 receptor monoclonal antibody, for the management of HHS. This receptor is triggered by 
inflammatory stimuli in various diseases. Binding of the antibody to IL-6 receptor inhibits the pro-inflammatory effects of IL-6. An improvement in inflammatory markers has been reported, which further supports the role of macrophage activation in red cell destruction in HS [51, $55]$.

\section{Conclusion}

Hyperhaemolysis syndrome is a life-threatening condition which may occur post-transfusion in SCD patients with marked haemolysis of transfused as well as autologous red cells. This is distinguished from DTHR which causes lysis of only donor red cells and is due to mismatch of the other red cell antigens not usually cross-matched in routine transfusion practice. It is believed to be due to red cell membrane abnormalities observed in SCD as well as genetic mutations of genes involved in synthesis of the complement-related proteins $M B L 2$ and KLCR3 responsible for regulation of the membrane attack complex. Affected patients have post-transfusion $\mathrm{Hb}$ lower than pretransfusion levels with $\mathrm{HbA}$ present in the urine. Treatment is to withhold further transfusion and commence on immunosupressive therapy and erythropoietin. It is imperative to carry out more extensive research to determine individuals who are more likely to be predisposed to this usually fatal complication; a high index of suspicion may be key in its management. There is also the need to monitor multiply transfused SCD patients in order to diagnose the condition and commence treatment as soon as HHS is suspected.

\section{Acknowledgements}

The authors acknowledge the input of the clerical and research staff of the Department of Haematology and Immunology of the College of Medicine, University of Nigeria.

\section{Statement of Ethics}

The authors adhered to the highest ethical standards in the writing of this review.

\section{Conflict of Interest Statement}

The authors declare no conflicts of interest.

\section{Author Contributions}

A.M. and O.U. designed this review. Literature search was done by C.E. and writing, and the manuscript was reviewed and edited by A.M., O.U., and C.E.

\section{References}

1 Ameen R, Al Shemmari S, Al-Bashir A. Red blood cell alloimmunization among sickle cell Kuwaiti Arab patients who received red blood cell transfusion. Transfusion. 2009;49(8): 1649-54.

2 Vichinsky EP. Current issues with blood transfusions in sickle cell disease. Semin Hematol. 2001 Jan;38(1 Suppl 1):14-22.

3 Allain JP, Stramer SL, Carneiro-Proietti AB, Martins ML, Lopes da Silva SN, Ribeiro M, et al. Transfusion-transmitted infectious diseases. Biologicals. 2009 Apr;37(2):71-7.

4 Sivapalaratnam S, Linpower L, Sirigireddy B, Agapidou A, Jain S, Win N, et al. Treatment of post-transfusion hyperhaemolysis syndrome in Sickle Cell Disease with the anti-IL6R humanised monoclonal antibody tocilizumab. Br J Haematol. 2019;186(6): e212-4.

5 Gouveia ME, Soares NB, Santoro MS, de Azevedo FC. Hyperhemolysis syndrome in a patient with sickle cell anemia: case report. Rev Bras Hematol Hemoter. 2015;37(4): 266-8.

6 Fasano RM, Miller MJ, Chonat S, Stowell SR. Clinical presentation of delayed hemolytic transfusion reactions and hyperhemolysis in sickle cell disease. Transfus Clin Biol. 2019 May;26(2):94-8.

7 Aygun B, Padmanabhan S, Paley C, Chandrasekaran $\mathrm{V}$. Clinical significance of $\mathrm{RBC}$ alloantibodies and autoantibodies in sickle cell patients who received transfusions. Transfusion. 2002;42(1):37-43.

8 Win N, New H, Lee E, de la Fuente J. Hyperhemolysis syndrome in sickle cell disease: case report (recurrent episode) and literature review. Transfusion. 2008;48(6):1231-8.

9 Talano JA, Hillery CA, Gottschall JL, Baylerian DM, Scott JP. Delayed hemolytic transfusion reaction/hyperhemolysis syndrome in children with sickle cell disease. Pediatrics. 2003 Jun;111(6 Pt 1):e661-5.

10 Mahapatra S, Baisakhi Panda B, Palai S, B Sahoo B, Parida P. Hyperhemolysis syndrome by Bystander mechanism in siblings with sickle cell disease. Trends Med. 2019;19(5).

11 Garratty G. What do we mean by "Hyperhaemolysis" and what is the cause? Transfus Med. 2012 Apr;22(2):77-9.

12 Aygun B, Padmanabhan S, Paley C, Chandrasekaran V. Clinical significance of RBC al- loantibodies and autoantibodies in sickle cell patients who received transfusions. Transfusion. 2002 Jan;42(1):37-43.

13 Mwesigwa S, Moulds JM, Chen A, Flanagan J, Sheehan VA, George A, et al. Whole-exome sequencing of sickle cell disease patients with hyperhemolysis syndrome suggests a role for rare variation in disease predisposition: WES in SCD patients with HHS. Transfusion. 2018 Mar;58(3):726-35.

14 Banks M, Shikle J. Hyperhemolysis syndrome in patients with sickle cell disease. Arch Pathol Lab Med. 2018 Nov;142(11):1425-7.

15 Win N, Doughty H, Telfer P, Wild BJ, Pearson TC. Hyperhemolytic transfusion reaction in sickle cell disease. Transfusion. 2001;41(3): 323-8.

16 Islam MS, Chia L. Hyperhemolysis syndrome in a patient with sickle cell disease with erythrophagocytosis in peripheral blood. Eur J Haematol. 2010;84(2):188

17 Pirenne F, Yazdanbakhsh K. How I safely transfuse patients with sickle-cell disease and manage delayed hemolytic transfusion reactions. Blood. 2018 Jun;131(25):277381. 
18 Lang KS, Lang PA, Bauer C, Duranton C, Wieder T, Huber SM, et al. Mechanisms of suicidal erythrocyte death. Cell Physiol Biochem. 2005;15(5):195-202.

19 van Meer G. Dynamic transbilayer lipid asymmetry. Cold Spring Harb Perspect Biol. 2011 May;3(5):a004671.

20 Chadebech P, Habibi A, Nzouakou R, Bachir D, Meunier-Costes N, Bonin P, et al. Delayed hemolytic transfusion reaction in sickle cell disease patients: evidence of an emerging syndrome with suicidal red blood cell death: suicidal RBC death as a mechanism of DHTR in SCD. Transfusion. 2009 Sep;49(9):1785-92.

21 Yazdanbakhsh K, Ware RE, Noizat-Pirenne F. Red blood cell alloimmunization in sickle cell disease: pathophysiology, risk factors, and transfusion management. Blood. 2012 Jul; 120(3):528-37.

22 Garratty G. The James Blundell Award Lecture 2007: do we really understand immune red cell destruction? Transfus Med. 2008; 18(6):321-34.

23 Sokolova A, Darabi K. A case of hyperhemolytic anemia. J Hematol. 2016 Mar;5(1):3840.

24 Morawakage LR, Perera BJ, Dias PD, Wijewardana SK. Hyperhemolysis in a patient with beta-thalassemia major. Asian J Transfus Sci. 2009 Jan;3(1):26.

25 Merrill SA, Brodsky RA, Lanzkron SM, Naik R. A case-control analysis of hyperhemolysis syndrome in adults and laboratory correlates of complement involvement. Transfusion. 2019;59(10):3129-39.

26 Mwesigwa S, Moulds JM, Chen A, Flanagan J, Sheehan VA, George A, et al. Whole-exome sequencing of sickle cell disease patients with hyperhemolysis syndrome suggests a role for rare variation in disease predisposition. Transfusion. 2018 Mar;58(3):726-35.

27 Pinto PCA, Braga JAP, Dos Santos AMG. Risk factors for alloimmunization in patients with sickle cell anemia. Rev Assoc Med Bras. NovDec 2011;57(6):668-73.

28 Petz LD, Calhoun L, Shulman IA, Johnson C, Herron RM. The sickle cell hemolytic transfusion reaction syndrome. Transfusion. 1997 Apr;37(4):382-92.

29 John Wiley \& Sons, Ltd. Frontmatter. Human blood groups; 2007. p. i-X.

30 King K, Shirey R, Lankiewicz M, YoungRamsaran J, Ness P. Delayed hemolytic transfusion reactions in sickle cell disease: simultaneous destruction of recipients' red cells. Transfusion. 1997 Apr;37(4):376-81.
31 Romano D, Craig H, Katz D. Management of cesarean delivery in a parturient with sickle cell disease. Int J Obstet Anesth. 2020 Feb;41: 104-7.

32 Aloni MN, Tshimanga BK, Ekulu PM, Ehungu JL, Ngiyulu RM. Malaria, clinical features and acute crisis in children suffering from sickle cell disease in resource-limited settings: a retrospective description of 90 cases. Pathog Glob Health. 2013 Jun;107(4):198-201.

33 Glikman D, Nguyen-Dinh P, Roberts JM, Montgomery CP, Daum RS, Marcinak JF. Clinical alaria and sickle cell disease among multiple family members in Chicago, Illinois. Pediatrics. 2007 Sep;120(3):e745-8.

34 Srinivasan A, Gourishankar A. A differential approach to an uncommon case of acute anemia in a child with sickle cell disease. Glob Pediatr Health. 2019 May;6 :2333794X19848674.

35 Rogers M, Smith G. Hyperhaemolysis in a patient with chronic lymphocytic leukaemia: letter to the editor. Transfus Med. 2014 Apr; 24(2):123-4.

36 Gupta S, Fenves A, Nance ST, Sykes DB, Dzik WS. Hyperhemolysis syndrome in a patient without a hemoglobinopathy, unresponsive to treatment with eculizumab: hyperhemolysis. Transfusion. 2015 Mar;55(3):623-8.

37 Treleaven JG, Win N. Hyperhaemolysis syndrome in a patient with myelofibrosis. Hematology. 2004 Apr;9(2):147-9.

38 Darabi K, Dzik S. Hyperhemolysis syndrome in anemia of chronic disease. Transfusion. 2005 Dec;45(12):1930-3.

39 Yan M, Callum J, Lin Y. Hyperhemolysis associated with marginal zone lymphoma. Leuk Lymphoma. 2015 Mar;56(3):829-31.

40 Eberly LA, Osman D, Collins NP. Hyperhemolysis syndrome without underlying hematologic disease. Case Rep Hematol. 2015; 2015:180526.

41 Ballas SK, Kesen MR, Goldberg MF, Lutty GA, Dampier C, Osunkwo I, et al. Beyond the definitions of the phenotypic complications of sickle cell disease: an update on management. ScientificWorldJournal. 2012;2012: 949535.

42 Eberly LA, Osman D, Collins NP. Hyperhemolysis syndrome without underlying hematologic disease. Case Rep Hematol. 2015; 2015:180526.

43 Karafin MS, Singavi A, Johnson ST, Field JJ. A fatal case of immune hyperhemolysis with bone marrow necrosis in a patient with sickle cell disease. Hematol Rep. 2017 Mar;9(1): 6934.
44 Tsitsikas DA, Gallinella G, Patel S, Seligman $\mathrm{H}$, Greaves P, Amos RJ. Bone marrow necrosis and fat embolism syndrome in sickle cell disease: Increased susceptibility of patients with non-SS genotypes and a possible association with human parvovirus B19 infection. Blood Rev. 2014 Jan;28(1):23-30.

45 Chou ST, Alsawas M, Fasano RM, Field JJ, Hendrickson JE, Howard J, et al. American Society of Hematology 2020 guidelines for sickle cell disease: transfusion support. Blood Adv. 2020 Jan;4(2):327-55.

46 Pirenne F, Bartolucci P, Habibi A. Management of delayed hemolytic transfusion reaction in sickle cell disease: prevention, diagnosis, treatment. Transfus Clin Biol. 2017 Sep; 24(3):227-31.

47 Hayes C, Shafi H, Mason H, Klapper E. Successful reduction of plasma free-hemoglobin using therapeutic plasma exchange: a case report. Transfus Apher Sci. 2016 Apr;54(2): 253-5.

48 Win N, Yeghen T, Needs M, Chen FE, Okpala I. Use of intravenous immunoglobulin and intravenous methylprednisolone in hyperhaemolysis syndrome in sickle cell disease. Hematology. 2004 Oct;9(5-6):433-6.

49 Noizat-Pirenne F, Habibi A, Mekontso-Dessap A, Razazi K, Chadebech P, Mahevas M, et al. The use of rituximab to prevent severe delayed haemolytic transfusion reaction in immunized patients with sickle cell disease. Vox Sang. 2015 Apr;108(3):262-7.

50 Bachmeyer C, Maury J, Parrot A, Bachir D, Stankovic K, Robert R, et al. Rituximab as an effective treatment of hyperhemolysis syndrome in sickle cell anemia. Am J Hematol. 2010 Jan;85(1):91-2.

51 Dumas G, Habibi A, Onimus T, Merle JC, Razazi K, Mekontso Dessap A, et al. Eculizumab salvage therapy for delayed hemolysis transfusion reaction in sickle cell disease patients. Blood. 2016 Feb;127(8):1062-4.

52 Arias CF, Arias CF. How do red blood cells know when to die? R Soc Open Sci. 2017 Apr; 4(4): 160850.

53 Risso A, Ciana A, Achilli C, Antonutto G, Minetti G. Neocytolysis: none, one or many? A reappraisal and future perspectives. Front Physiol. 2014;5:54.

54 Gardner K, Hoppe C, Mijovic A, Thein SL. How we treat delayed haemolytic transfusion reactions in patients with sickle cell disease. Br J Haematol. 2015;170(6):745-56.

55 Lee LE, Beeler BW, Graham BC, Cap AP, Win $\mathrm{N}$, Chen F. Posttransfusion hyperhemolysis is arrested by targeting macrophage activation with novel use of tocilizumab. Transfusion. 2020;60(1):30-5. 